\title{
John Mystery and the Australian Book Trade
}

\section{Juliet O’Conor}

\section{Deakin University}

The Children's Literature Collection at the State Library of Victoria holds over 100,000 Australian and overseas children's books published between the sixteenth and twenty-first centuries. In 1994 this collection was significantly enhanced through the acquisition of the Ken Pound collection of children's books and ephemera. When buying at local fairs and markets over twenty-five years, Ken Pound made no distinction between quality of content or ephemerality. If a publication addressed a child readership, Ken Pound added it to his collection. The State Library's acquisition of this collection means that publications from small Australian publishers, variant editions of titles, advertising, merchandising and other ephemeral material augment the existing strengths of the Children's Literature Collection. The comprehensive scope of the Australian component of this heritage collection of children's books positions it as a unique research resource for children's literature scholars.

I begin by identifying the factors that operated to relegate the John Mystery children's books to the forgotten basket of Australian literary heritage. The John Mystery emporium occupied a niche in the Australian book trade at a time when existing Australian publishers were minimizing output due to war-time restrictions on labour and materials. In contextualizing the John Mystery phenomenon, I compare the flamboyance and eccentricity of the creator, Lester Sinclair, with the earlier entrepreneur, E. W. Cole, who employed similarly theatrical marketing strategies. Also, I interrogate content of a selection of John Mystery titles and reflect on the values embedded in these seemingly innocent escapist fantasies. Finally I will suggest how the State Library of Victoria's heritage collections present potential resources for scholars of children's literature.

\section{John Mystery}

The scope of national literatures is recorded in bibliographies. Marcie Muir was the first bibliographer to seriously approach the task of recording Australian children's literature. The first edition of A Bibliography of Australian Children's Books (Muir 1970) was published in two volumes in 1970 and 1976. In volume one, Muir makes brief reference to the John Mystery books as an example of cheap production methods employed during World War II and supplies an abbreviated entry for seven series titles of John Mystery books. Muir's description dismissively 
suggests that the John Mystery books consist of 'A number of series of paper-covered picture books anonymously published and mostly of non-Australian subject matter and considered unworthy of detailed entry' (1970, p.443). Six years later in volume two, Muir gives a full entry to only one title noting Australian content (1976, p.283).

The following decade in 1989 a select bibliography, Australian Children's Books to 1980: A Select Bibliography of the Collection Held in the National Library of Australia compiled by Terence and Frances O’Neill, gives full entries for four John Mystery titles (O’Neill \& O'Neill 1989, pp.102103). Given Muir's dismissiveness of John Mystery content, it is significant that in the intervening seventeen years, O'Neill and O'Neill's select bibliography found Australian content in four titles. Subsequently in Muir's 1992 updated bibliography, full entries are listed for sixty-seven John Mystery titles (Muir 1992, pp.290-293). However, Muir notes in both editions that she compiled her entries from the holdings of major research libraries and private collections of Australian children's books specifically noting what was then the large, privately owned Ken Pound collection. When the State Library of Victoria acquired the Ken Pound Collection in 1994, the cataloguing team headed by Derrick Moors found a much larger collection of over ninety John Mystery titles (Moors 1997). Ken Pound continues to donate to the Library's Children's Literature Collection and it is conceivable that he found over twenty additional John Mystery titles after publication of Muir's updated bibliography. However, it is probable that Muir continued to resist full bibliographic entries for the John Mystery books because she perceived they were not particularly worthy elements of the Australian child's literary heritage.

In 1997 children's literature scholar, Clare Bradford interviewed Ken Pound about his collection of children's books. In particular, Bradford notes Ken Pound's respect for children's books and how his collecting approach was at variance with attitudes of many book dealers and bibliophiles who considered children's books unworthy of serious attention (Bradford 1998, p.328). Muir's reluctance to list John Mystery books in Australia's foremost bibliography of children's books is indicative of persistent judgements about quality that privilege some elements of literary history. I suggest that a comprehensive approach to children's book history, made tangible through the scope of the State Library's Children's Literature Collection, through increasing knowledge of lesser known publishing enterprises in the Australian book trade enhances such social and literary understanding .

John Mystery books have become collectable today. I estimate that there are likely to be between three and four hundred John Mystery titles. At the time of writing, the largest holdings are at the State Library of Victoria consisting of two hundred and forty-two titles plus numerous cards, records and other ephemera. The National Library of Australia holds one hundred and thirty-four titles, Monash University holds seventy titles and other libraries have smaller holdings. Three Sydney printers published different series of John Mystery books including Publicity Press, Lonsdale \& Bartholomew, and John Mystery Productions. Lonsdale \& Bartholomew published a separate series of John Mystery books called the J. M. Merrythought range which was distributed exclusively through Myer in Melbourne. None of the John Mystery series is dated and illustrators 
are not always acknowledged. For example, the illustrator Matt Heriot sometimes signs his illustrations as ' $\mathrm{M}$ ' or 'Matt', but his contribution otherwise remains unacknowledged. Derrick Moors (Moors 1997) estimates the dates of publication to be between 1938 and 1952 based on his knowledge of the Australian book trade and content of the Dear Cobber letter, a device used in many John Mystery books to communicate with readers. Moors notes that some versions of the Dear Cobber letter reference the war (p.37) enabling the approximation of publication dates. In several John Mystery titles, the Dear Cobber letter informs readers of impending international distribution and cites World Managers to be Spicers (Export) Ltd in New Bridge Street, England. However, to date no confirmation that John Mystery books were distributed overseas has been established.

\section{Children's Book Entrepreneurs}

Publication of children's books in Australia began a considerable time after the means to print arrived with the First Fleet in 1788. Initially British settlers focused on printing pamphlets and newspapers rather than novels, plays and books of verse. The first children's book published in Australia, A Mother's Offering to her Children (Barton 1841), was published by The Sydney Gazette and New South Wales Advertiser newspaper in 1841. Population of cities like Sydney and Melbourne grew to 500,000 inhabitants in half a century after the 1850 s gold rush. With population growth came the development of entrepreneurial enterprises to supply goods to the expanding market. E.W. Cole (1832-1918) established his famous Cole's Book Arcade, contentiously a bookshop and cultural emporium, in Melbourne in 1873. This emporium sold a range of Australian and overseas books for children and adults. To attract attention to his bookshop, Cole had two mechanical men placed at the entrance turning advertising boards and above the doorway a painted rainbow. His most successful publication, Cole's Funny Picture Book (Cole 1885) launched with great publicity in 1879, contained an idiosyncratic combination of religion, showmanship and advertising. Later enlarged premises enabled Cole to introduce new attractions enhancing the carnival atmosphere of his premises. His arcade offered a Wonderland of optical illusions and a penny-in-the-slot Hen That Laid the Golden Eggs. In 1898 Cole opened branches of Cole's Book Arcade in Sydney and Adelaide. Cole's arcades declined in prosperity early in the twentieth century. The Sydney branch closed in 1924, the Adelaide branch was bought by its manager, while Melbourne's Coles Book Arcade wound up in 1929.

The following decade a similar combination of showmanship and eccentricity fuelled the entrepreneurial spirit of Lester Sinclair (1899-1974) through his creation of the publishing phenomenon of the John Mystery brand of children's literature. Like the Melbourne cultural emporium of Coles Book Arcade, Sinclair built his own emporium on the Illawong Peninsula in southern Sydney and called it Adventure Castle. A drawing of Adventure Castle appears on the back cover of many of the John Mystery titles and served as a reminder for his readers to visit with their mothers and purchase his books, cards, vinyl records and other ephemeral material. In addition Sinclair blended patriotism with the clever marketing strategy of writing to his readers through his Dear Cobber letters which were printed on the inside cover of many of his books. 


\section{Promotion of the John Mystery Brand}

Research by Chris Vening and David Overett soon to be published, uncovers much of the intrigue surrounding the life of the man behind John Mystery. They reveal that Lester Sinclair used several names during his lifetime including his birth name James Basil Pearson. Sinclair emigrated from the United Kingdom to Australia in 1914, served in the Australian Imperial Forces for a short period, and later worked as a song writer, theatre manager, comedian, vaudeville performer and publicity manager in New Zealand and Australia. His wife Ellen Sinclair, a published author and journalist, is likely to have contributed to the John Mystery literary output (personal communication with Moors and Vening) despite the lack of acknowledgement in publication. Lester Sinclair's promotional and vaudevillian experience positioned him well to begin an enterprise that captured the imagination of Australian children as an antidote to the seriousness of a country involved in World War II.

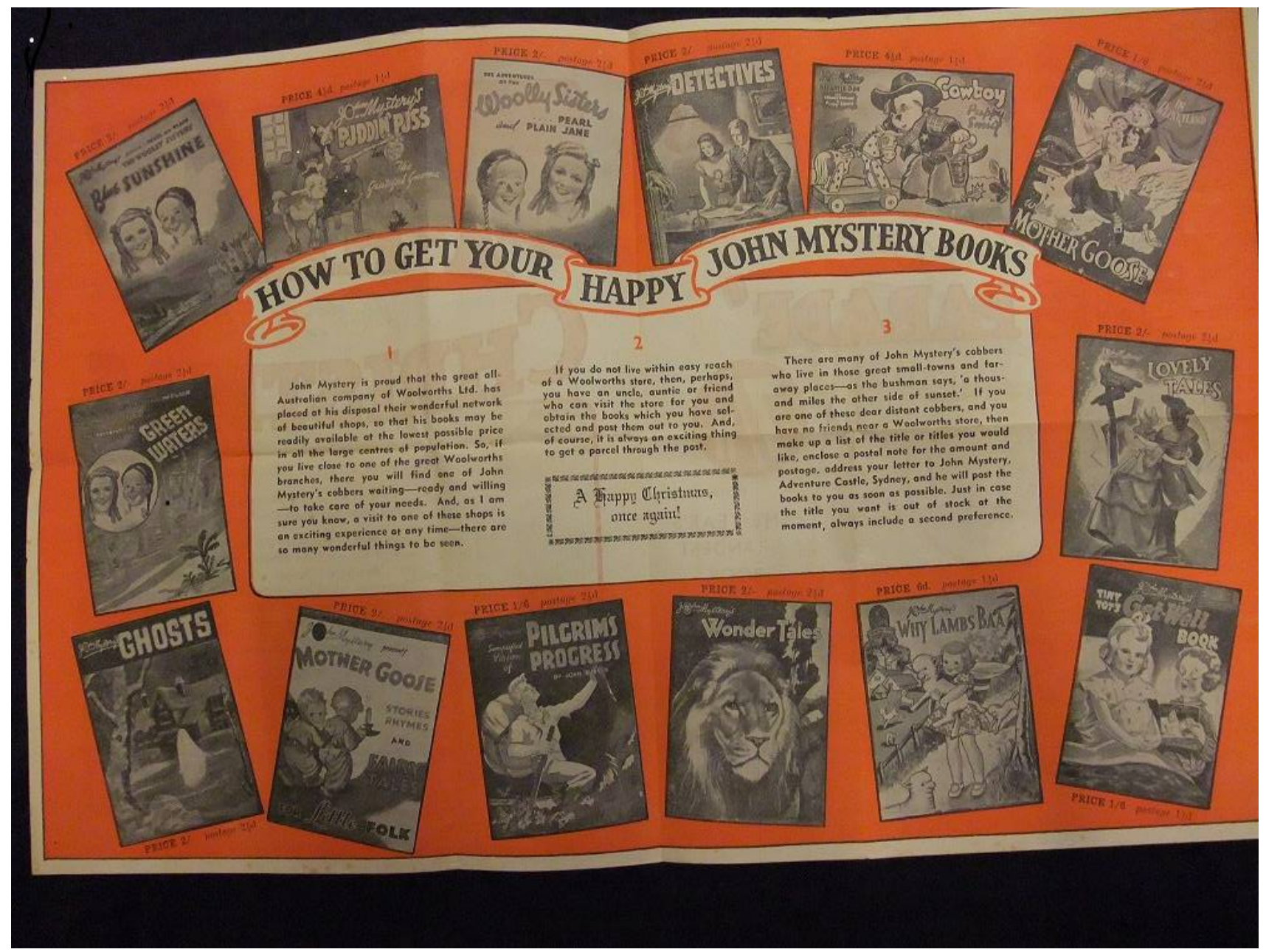

Figure 1. Christmas Promotional poster showing prices of titles.

Sinclair uses a number of strategies for the promotion of his books. The Dear Cobber letter speaks directly to his readers with requests they write to him and tell him whether they like his books and what kind of stories readers would like to hear. Some Dear Cobber letters encourage readers to send a stamped self-addressed envelope to receive by return post coloured beans found in a chest in Adventure Castle. Mystery describes how a parchment in the chest identifies these beans to have come from Jack's Magic Beanstalk and though the beans were no longer magic they possessed emotional qualities that bestow happiness and wellbeing. Illustration of Adventure Castle beckons 
John Mystery's audience to visit the castle. Once there, Sinclair offers visitors a Lucky Shell and leaflet with the suggestion of a universal panacea.

This Lucky Shell, a wondrous thing,

Contains the down from a fairy's wing;

The Fairy who guards us all from harm-

Against all hurt, a magic charm.

(Mystery undated, leaflet)

John Mystery encouraged children to keep their Lucky Shell wherever they go so that good fortune would travel with them. Other ephemeral John Mystery merchandise held in the Library's Children's Literature Collection archive includes get well, birthday and Christmas cards. Some cards open to a small vinyl recording with instructions on how to play the greeting.

In Australia and overseas potential existed for the mass distribution of inexpensive children's books during World War II. In America Simon and Schuster published twelve titles in their new line of Little Golden Books in 1942 and distributed them through supermarkets and department stores. In Australia, Sinclair also targeted department stores and in 1944 his financial records show sales to Woolworths of 4.5 million copies from a repertoire of 228 titles. Two years later Woolworth's sales figures increased to 5 million copies (Moors 1997, p.32). John Mystery's Christmas promotion (Figure 1) shows the variety of content from Mother Goose stories, how and why rhymes for young children to his Woolly Sisters series and abridgements such as Pilgrims Progress for older children. This poster gives the price of each title between two shillings and four and a half pence. In Australia in 1940, the cost of bread was five pence a loaf and the cost of a bottle of milk was seven pence. The John Mystery books were therefore priced to be affordable for most families during the austerity measures of the war.

\section{Imperial Ideology in Content}

John Mystery books are relentlessly cheerful, offering readers messages of the importance of healthy thoughts and altruistic actions. These narratives encourage optimism in language which promises high adventure in bumper books about merry and happy characters in exciting stories. Echoes of Sinclair's theatrical background are evident on the cover of John Mystery's Cobbers: Australian Children's Annual (Mystery 1945-1950) where fantasy characters perform amusing antics in the foreground and smiling children peer over an opened book with the title 'Exciting Things to Read and Do'. In the tradition of pantomime, where actors carry signs across stage with messages for the audience, other characters on the cover of the annual hold a contents list showing that this issue contains new stories, games, puzzles, party pranks and hobbies.

Threats of wild animals and other perils are foreshadowed in titles like Thrill Time for Boys (Mystery 1950). This collection of six stories opens with the chapter 'Swamp Sinister', a story about two chums, Jerry and Toby who investigate a strange threat to a sheep station owned by Jerry's father, Mr Champion. The use of terms like 'chums' for the friendship between two young boys, the family surname and descriptors of the unknown threat as the 'bogey man' are signifiers of 
imperial ideology embedded in a narrative positioned at the frontier of adventure. Elements such as the isolation of an Australian outback property and the vulnerability of the Champion nuclear family to physical harm are archetypes of colonial settler narratives. One evening Joan, the youngest daughter of $\mathrm{Mr}$ and Mrs Champion, wakes in fright and immediately her family gathers by her bedside. There they discover that Joan's favourite doll has been stolen. The theft of Joan's doll is the culmination of a series of farm incidents and becomes the impetus for a search party. Near tragedy for the search party is averted when Mr Champion shoots the two gorilla culprits. The following day a local police inspector explains that the gorillas were known to have escaped a travelling circus five years ago. The gorillas had been chained, branded and taught to perform in the circus using knives. The gorillas used their knife skills to kill one of Mr Champion's sheep. The narrative employs traditional gender role models. Mrs Champion is the nurturing homemaker, $\mathrm{Mr}$ Champion the victorious hunter and provider and the chums are eager to avenge the youngest female's loss. This postcolonial narrative acts as an agent of the empire builders by defending family, asserting ownership of property and assuming the higher moral position over the cruelty exerted upon circus animals.

In the first double page of My Big Book of Aeroplanes (Mystery 1943) an illustration of Merrythought Land is placed opposite three symbols of the war. On the hilltop of Merrythought Land stands Adventure Castle from which fairy tale characters, circus clowns and animals tumble downhill. Illustrated opposite is the Flying Fortress, a bomber plane first used in 1935 then extensively during World War II, with two battle ships on the sea below. Though the Flying Fortress is described as the most powerful war plane, the accompanying verse focusses on the plane's technical capacity.

Into the Stratosphere.

Into the unknown, go the famous

FLYING FORTRESSES,

Most powerful war planes the world

Has ever known!

They travel great distances

Carrying heavy loads

At almost unbelievable heights.

(Mystery 1943, unnumbered first double page)

The inability to acknowledge any destructive element in the machinery or purpose of war is a recurring motif in the John Mystery literary style. Embedded in the ever-present optimism of the narrative is the power of association with British armed forces. This juxtaposition of the theatre of fantasy opposite the theatre of war reflects an ideology that equates idealism with imperial hegemony.

One John Mystery series does have an unhappy protagonist. Each of the titles in the Puddin Puss Series begins with Mystery's explanation 'All About Puddin Puss'. Mystery tells his readers how he was inspired to write this series. One cold morning when he went down to Adventure Castle's 


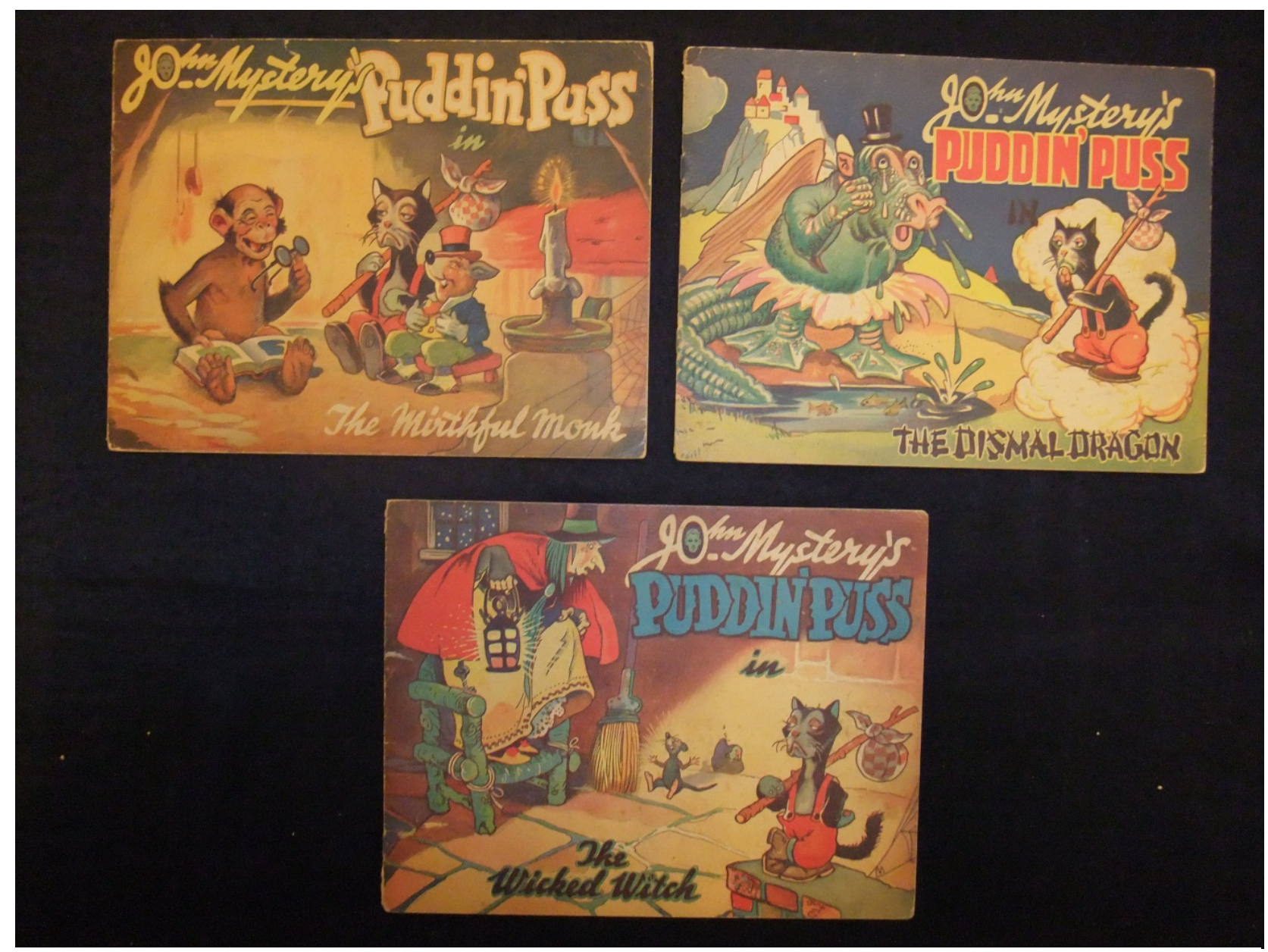

Figure 2. Selection of titles in the Puddin Puss Series

kitchen, he found a thin black kitten curled up in the middle of the saucepans. The starving kitten would only eat rice pudding, so John Mystery named him Puddin Puss. A little mouse, Dicky Doodle Dormouse, would emerge from hiding in a crack near the Castle door each night and join Puddin Puss in an adventure. On those adventures Puddin Puss always carries a basin filled with rice pudding. Mystery concludes his preface with the observation that Puss never laughs (Figure 2) and the authorial voice engages readers by rhetorically wondering if Puss ever will be happy.

The story John Mystery's Puddin Puss in the Dismal Dragon (Mystery 1944a) is written in verse for young children and is about a sad dragon who cries all day near Adventure Castle. The dragon's tears fill the castle moat with salt which disturbs the fish. So Puddin Puss and Doodle Mouse determine to stop the dragon crying. When Puddin Puss accidently throws his pudding basin at the dragon, its return buries Doodle Mouse in pudding dough. The dragon finds this very funny and leaves happy but Puddin Puss still does not smile though he is the agent of the dragon's happiness. In John Mystery's Puddin Puss in the Mirthful Monk (Mystery 1944b) a wise monkey called Monkey Chan makes many humorous quips but still fails to make Puddin Puss smile. The happiness/unhappiness binary is again the focus of John Mystery's Puddin Puss in the Wicked Witch (Mystery 1944c). In the valley outside Adventure Castle lives a witch who casts spells on happy dogs to stop their tails wagging. Puddin Puss enlists the help of a swarm of bees on his way to the witch's house. When the witch opens her door the bees engulf her and she flees panic stricken. The witch trips and falls to her death in her haunted well. The aim of these short verse 
stories is reader recognition that good deeds are their own reward. The didacticism is lightened through a device that encourages collusion between author and reader in knowing that Puddin Puss should be happy about the outcome.

In John Mystery's Sweethearts Good Book (Mystery 1945-1950) the Dear Cobber letter is replaced with 'The Look Out of Adventure Castle'. From the Castle's east tower Mystery sees the Armies of Youth come towards the castle at sunrise. The phrase 'Armies of Youth' recalls reference to Hitler Youth, children manipulated by Nazi propaganda to perform acts of inhumanity. The illustration of John Mystery's Armies of Children overtly emphasises multiculturalism in the national costume worn by the children. This illustration fixes diversity in cultural archetypes deliberately challenging the philosophy behind the future Aryan race of Hitler Youth. This is a rare if oblique narrative statement about the reality of the war and how it can involve children. Though the illustration of John Mystery's Armies of Children smile and touch each other, the cohesiveness of the group is undermined by the clothing that identifies their nationalities. The children are assembled to enforce the authorial position and inevitably to advertise how John Mystery books can be enjoyed worldwide. Ever the promoter, Mystery concludes his Look Out from Adventure Castle message by suggesting the children will find exciting books for all ages listed at the back of this book.

Short catchy verse is frequently employed in the John Mystery books as a strategy of socialisation. In the Preface to In Blinkyland with Grimm (Mystery 1945) readers learn how evil is vanquished:

Where, treading the wonderways of youth,

The Royal King Supreme is Truth,

With Honesty the sparpest tool. And Wickedness... a hunch back fool..

(Mystery c1945, unnumbered Preface)

Much is made of human traits of honesty and truth while ridiculing their opposites. It is therefore ironic that the John Mystery Blinky Land series establishes a premise for retelling the intellectual property of others. The first book in the series describes how John Mystery accompanied by two children go to Blinky Land to ask Hans Christian Andersen's permission to retell his stories. The children, Martha and John, live with their parents in a windmill and one evening begin their journey with Mystery by leaping from the sails of the windmill. On their way, an old man explains that Blinky Land is the place where rainbows begin, where authors and artists go when they die. If children have written good compositions or drawn nice pictures at school they too will go to Blinky Land when they die. This premise is applied in later books in this series where the children accompany Mystery to ask for permission from the Brothers Grimm, Mother Goose and Fairy Beauty. 
The sisters Pearl and Plain Jane Woolly appear in a number of series (Figure 3) and must have been popular characters for readers. The first Woolly Sisters book, Adventures of the Woolly Sisters: Pearl and Plain Jane (Mystery 194?), introduces each character separately. Pearl and Plain Jane take a bow when introduced to the reader as Australian girls who are just as adventurous as Alice in the Lewis Carroll books. An array of Australian animals in anthropomorphic form is introduced in succession. Mr and Mrs Peter Pigeon are suggested to have descended from the pigeons that Noah took on the ark during the great flood. Mystery offers an explanation of the strange appearance of the Australian platypus in his introduction of Dr Platypus and Mrs Platypus. On Noah's ark of an evening all the animals would take off their coats and shoes and hang their beaks behind the door. When the ark landed at Mount Ararat the platypus was the last to leave and had to be content with what clothes were left. So he had to wear a duck's beak and shoes and a fur coat. Mystery suggests that Ernie the Emu has a long neck because Noah asked him to keep a lookout for rocks which might damage the ark in a storm.

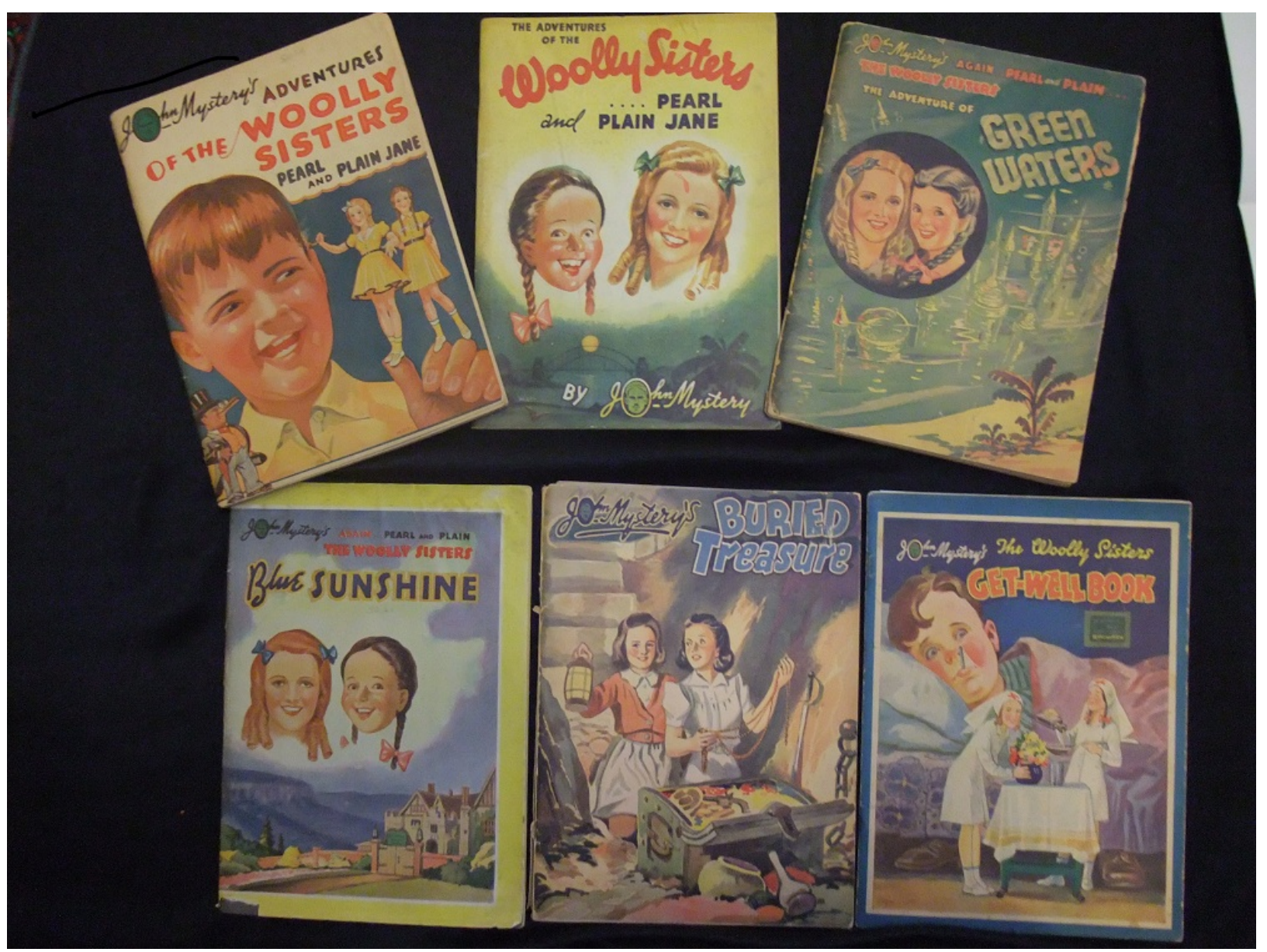

Figure 3. John Mystery’s Woolly Sisters Series

The first chapter of Adventures of the Woolly Sisters: Pearl and Plain Jane is called The Land of Magic Trees where plum trees grow plum puddings in cloths, tins and basins all ready to be eaten. Similarly there is a pork pie tree, a custard tart tree, a doughnut tree and a cream puff tree. The next garden has trees with underpants, flannel vests and men's suits. Another garden grows hot dinners on plates with knives and forks attached. Altogether there are nine gardens with the last, the Money Garden. All the rivers from the other gardens flow into this Money Garden. If the other trees are 
weak then the Money Garden does not grow, but if the other gardens are strong and healthy, then the Money Trees grow the biggest in the garden. Told to choose anything for themselves, Plain takes a Good Fortune Flower and Pearl takes a Flower of Happiness. The girls then sail home across Sydney Harbour in a giant's shoe with the Sydney Harbour Bridge in the background. The absurdity of this fantasy has easily recognisable associations with Lewis Carroll's books with the notable exception of the Money Garden and the self-consciousness of the sisters' altruism. This narrative negotiation of social personhood through the altruism of the protagonists is curiously constructed within a capitalist framework.

The remaining chapters include The Valley of the Witches, The Crooked House, Moon Madness, The House of the Five Sisters, The Hall of Clocks, The Pool of Recollections, The New World, The Magic Ring and The Land of Tomorrow. Ideology embedded in the later chapters in this book is interesting to reflect upon. In 'The Pool of Recollections' the Woolly Sisters watch the beginning of Australia. After a long journey in complete darkness the giant brings the sisters to a storm covered, forbidding range of mountains. As they shelter in a cave the trio see in the distance a young boy approach them carrying a lantern. The boy introduces himself as Hope so named because 'Hope is young-and happy-and that's what I am' (Mystery c194?, p.77). Hope leads the giant and the sisters to another cave and the Pool of Recollections. The girls notice that the pool changes from dark and oily in appearance to bright and full of light. Hope explains that when the pool reflects what has passed, it becomes dark signifying times of fear or sorrow then changes to lightness corresponding to periods of happiness. To find out how Australia began, Hope tears aside time to one million years before any people came here. This is when the children see a murky pool filled with figures of hundreds of horrible shapes. Hope declares these to be demons. A veritable pageant unfolds as the demons disappear and the land of Australia becomes dark. Neither a warming sun nor moon enables the definition of any landforms. This passes and the pool fills 'with the gay colours of the rainbow' (p.78). Then five sisters representing the stars of the Southern Cross appear and in front of them on a stairway appears a figure called Destiny 'a tall, bronzed man in shining armour. Upon his forehead, in letters of fire, was the word DESTINY' (p.78). The female form of the Southern Cross stars is depicted as five western adolescents wearing knee high dresses and heeled shoes. Destiny himself is a commanding figure with a strong jaw and European features. He is a caped crusader with metal helmet and armour and with outstretched arms resembles a religious cross. Dramatically the sound of trumpets calls the shrieking demons to the foot of the stairway where Destiny banishes them from the land of Australia and proclaims that the Demons of Darkness, Stillness, Stealth, Stagnation and Decay will die and only Fire and Drought can remain. Destiny's message is one of happiness and wellbeing in his proclamation that 'this will be a wonderful land, full of richness and good-fortune, of health and happiness' (p.80). As a creation narrative, this chapter combines allegories of Christian beliefs, archetypes of medieval crusaders and contemporary comic superheroes. It is significant that the narrative while set in Australia makes no reference to Indigenous Australian belief systems. At the conclusion of the chapter, Destiny brings forward five Australian animals to which he ascribes admirable human qualities. For example the cockatoo represents free speech and the platypus represents versatility. There is potential at this point to introduce notions of Indigenous Australian totemic associations. The absence of any reference to 
Aboriginality is significant in a narrative that overtly promotes the uniqueness of Australia with the promise of good fortune, health and happiness.

The final story in The Adventures of the Woolly Sisters Pearl and Plain Jane, 'The Land of Tomorrow', predictably opens with the suggestion of future adventures with the Woolly Sisters in other books. However, it is also interesting to examine what constitutes the Land of Tomorrow. Ever present is an authorial determination to socialise readers. First the Dream Boat takes children over the border of Night to the brightness of the Land of Tomorrow. In contrast, the Land of Yesterday is full of darkness and decay and ruled by the Demon Precedent. Nothing grows there, nothing new happens and the inhabitants want to always live in the past so have nothing to look forward to. Demon Precedent finds no beauty in anything and proclaims that if it hasn't already been done then you can't do it and 'at his command he has millions of Red Tape Snakes, with eyes of fire!' (p.93). Overhead the Land of Yesterday floats the Land of Memory filled with 'gay, happy, laughing little fairies' (p.93). Quickly passing through the Land of Yesterday, children come to a gateway where Hope with his lantern sets them upon a broad white road. On the right is a Pit of Broken Promises being mended by hundreds of happy workers. The children may see the strange looking Dream Incubator where eggs are warmed by Hope and lit by Ambition and emerge ready to be used. Children can throw all their wishes into the Wishing Machine and if it's a good wish it will come true. The Bank of Zeal holds no money but takes deposits of good wishes. Outside the Bank are a band of four beggars comprising Tommy Too-Tired, Bobby Can't-Be-bothered, Charlie Doesn't-Care and Nobby Know-All. The concluding message of altruism is that children should show the four beggars 'that happiness is a thing for which they must strive, that good wishes must be earned. You will teach them the way to true prosperity of spirit — which is in working hard and giving joy to others.' (p.96) Authorial comments in The Land of Yesterday and The Land of Tomorrow can be appreciated by child readers on one level but references to red tape snakes shifts audience understanding to a different plane of life experiences.

Children's literature routinely attempts to socialise readers. John Mystery books contain an overt didactic message that positive thoughts will lead to happiness and sunshine. These narratives avoid acknowledging the present trauma of war. Instead when catastrophe is represented, such as the demon pageant at the beginning of Australia, the narrative leaps contemporary issues and focusses on mythical associations. The intention of the John Mystery books is clearly to be light amusement through adventurous fantasies for boys and girls. These fantasies are deliberately unrecognisable fictions and offer diversion from the trauma of war rather than comfort through the disclosure of fears associated with wartime.

\section{Research Resources}

Research for this article would not have been possible without the archives held in the Children's Literature Collection at the State Library of Victoria. The pre-eminence of the Australian component of the State Library of Victoria's Children's Literature Collection is due to an ongoing policy for the comprehensive collection of mainstream and smaller independent publishers of children's books. The Children's Literature Collection scope, development and history are outlined 
on the State Library of Victoria's website http://slv.vic.gov.au/our-collections/collectionstrengths/childrens-books where electronic guides http://guides.slv.vic.gov.au/ assist researchers find resources on specific subjects, genres and primary sources such as legislation. A broad range of academic resources supports the primary materials, all of which are held onsite and available for researchers to request and use on Library premises. The Library's Children's Literature Research Guide http://guides.slv.vic.gov.au/childrensliterature suggests pathways to access primary and secondary resources, links to electronic databases and full text digital content. The Children's Literature Collection is fully catalogued and collection items can be accessed through the online catalogue http://www.slv.vic.gov.au/explore/research-tools It is anticipated that once full searching capability is resolved for digitized text, digitization of parts of the Children's Literature Collection, such as nineteenth and twentieth century magazines and rare out-of-copyright items, will complement the Library's existing programme of digitized maps, pictures and pamphlets. The State Library ensures the longevity of collection items by housing them by format. This means that children's books and magazines are housed separately to artists' work that may illustrate children's books and separate again from preliminary drafts and unpublished manuscripts. For example the young adult novels by the author Sonya Hartnett are held in the Library's Children's Literature Collection while her manuscript archive relating to ten of her young adult books is lodged with the Australian Manuscripts Collection. Though not yet fully catalogued, Hartnett's manuscript material can be made available for researchers upon request. Similarly the artist Leigh Hobbs' picture books are held in the Library's Children's Literature Collection and an archive of artwork by or about Hobbs is lodged with the Library's Pictures Collection. Preservation, storage and conservation of archival material require specific conditions. In the Hobbs pictorial archive, housing addresses the needs of works on paper such as preparatory drawings for the Old Tom books, an oil painting of Hobbs by Anne Spudvilas submitted for the 2000 Archibald Prize and two earthenware teapots made by Hobbs in the shape of Flinders Street Station.

The State Library of Victoria offers an annual programme of funded and honorary Creative Fellowships http://www.slv.vic.gov.au/our-community/fellows-scholars/creative-fellowships aimed at encouraging innovative research using the Library's unique collection material. Fellowship applicants can frame their research proposal noting relevance to resources in the Library's Collections http://www.slv.vic.gov.au/our-collections. Children's literature scholars may propose projects that access a number of the Library's heritage collections. Applications should emphasise access to collection items not held elsewhere. The John Mystery collection discussed here is one example of how comprehensive institutional collecting can enhance the success of fellowship applicants.

\section{References}

Barton, C. (1841) A Mothers Offering to Her Children. Sydney, Gazette Office.

Bradford, C. (1998) '(Re)Constructing Australian childhood: the Pound Collection at the State Library of Victoria, Australia', The Lion and the Unicorn 22, 3, 327-337.

Cole, E. (c 1885) Coles Funny Picture Book. Melbourne, Coles Book Arcade.

Moors, D. (1997) 'John Mystery: ‘the nation's story teller', La Trobe Journal 60, 31-39. 
Muir, M. (1970-1976) A Bibliography of Australian Children's Books. London, Deutsch.

Muir, M. (1992) Australian Children's Books: A Bibliography Volume One 1774-1972. Carlton, Vic., Melbourne University Press.

Mystery, J. (c 194?) Adventures of the Woolly Sisters: Pearl and Plain Jane. Sydney, Publicity Press.

Mystery, J. (c 1943) My Big Book of Aeroplanes. Sydney, Lonsdale \& Bartholomew.

Mystery, J. (c 1944a) John Mystery's Puddin Puss in the Dismal Dragon. Sydney, Publicity Press.

Mystery, J. (c 1944b) John Mystery's Puddin Puss in the Mirthful Monk, Sydney, Publicity Press.

Mystery, J. (c 1944c) John Mystery's Puddin Puss in the Wicked Witch. Sydney, Publicity Press.

Mystery, J. (c 1945) In Blinkyland with Grimm. Sydney, Publicity Press.

Mystery, J. (c 1945-1950) Cobbers: Australian Children's Annual. Sydney, Lonsdale \& Bartholomew.

Mystery, J. (c 1945-1950) John Mystery’s Sweethearts Good Book. Sydney, Publicity Press.

Mystery, J. (c 1950) Thrill Time for Boys. Sydney, Lonsdale \& Bartholomew.

O’Neill, T. \& O’Neill, F. (1989) Australian Children's Books to 1980: A Select Bibliography of the Collection Held in the National Library of Australia. Canberra, National Library of Australia.

State Library of Victoria, Children's Literature Collection. Available from: http://slv.vic.gov.au/ourcollections/collection-strengths/childrens-books [Accessed 30 March 2012].

State Library of Victoria, Creative Fellowships. Available from: http://www.slv.vic.gov.au/ourcommunity/fellows-scholars/creative-fellowships [Accessed 30 March 2012].

State Library of Victoria, Heritage Collections. Available from: http://www.slv.vic.gov.au/ourcollections [Accessed 30 March 2012].

State Library of Victoria, Online Catalogue. Available from: http://www.slv.vic.gov.au/explore/research-tools [Accessed 30 March 2012].

State Library of Victoria, Research Guides. Available from: http://guides.slv.vic.gov.au/ [Accessed 30 March 2012].

State Library of Victoria, Research Guides, Children's Literature. Available from: http://guides.slv.vic.gov.au/childrensliterature [Accessed 16 August 2012].

Vening, C. \& Overett, D. (unpublished manuscript) 'In Search of John Mystery'.

\section{SOCR}

\section{Biographical note}

Juliet O'Conor is the Children's Research Librarian at the State Library of Victoria responsible for over 100,000 Australian and overseas children's books published between the $16^{\text {th }}$ and $21^{\text {st }}$ centuries. Her ongoing doctoral study at Deakin University examines a selection of $20^{\text {th }}$ century Indigenous Australian traditional stories for children. 